\title{
Effect of Mercuric Compounds on Pine and Sycamore Germination and Early Survival
}

\author{
Sharon R. Jean-Philippe ${ }^{1}$, Nicole Labbé ${ }^{2}$, Jeremie Damay ${ }^{3}$, Jennifer A. Franklin ${ }^{1}$, Karen Hughes $^{4}$ \\ ${ }^{1}$ Department of Forestry, Wildlife, and Fisheries, University of Tennessee, Knoxville, USA; ${ }^{2}$ Department of Forestry, Wildlife and \\ Fisheries, University of Tennessee, Center for Renewable Carbon, Material Science \& Technology, Knoxville, USA; ${ }^{3}$ ENSTIB- \\ LERMAB, University of Nancy 1, Epinal, France; ${ }^{4}$ Ecology and Evolutionary Biology, University of Tennessee, Knoxville, USA. \\ Email: jeanphil@utk.edu
}

Received September $13^{\text {th }}, 2011$; revised October $25^{\text {th }}, 2011$; accepted November $29^{\text {th }}, 2011$

\begin{abstract}
Mercury pollution has become an important current issue as a result of its environmental effects on a global scale. The Oak Ridge Reservation, established in 1942, was the designated site for the construction of the atomic bomb. During a 20-year period from 1944-1963 radioactive and toxic chemical pollutants, especially mercury compounds were released into the surrounding waterways. A germination study was conducted to investigate the ability of three tree species, American sycamore (Platanus occidentalis), shortleaf pine (Pinus echinata), and loblolly pine (Pinus taeda) seeds to germinate in mercuric nitrate $\left(\mathrm{Hg}\left(\mathrm{NO}_{3}\right)_{2}\right.$ and methylmercury chloride $\left(\mathrm{CH}_{3} \mathrm{HgCl}\right)$ solutions. A subsequent greenhouse study was conducted to assess the phytotoxic effects of different mercuric solutions on Platanus occidentalis (American Sycamore), inoculated with soils from East Fork Poplar Creek. We also measured vegetation stress by Near Infrared (NIR) spectroscopy. The wavelengths examined were those thatare specific to chlorophyll and several carotenoids, which are involved in photosynthesis: $430 \mathrm{~nm}(\mathrm{Chl} a), 448 \mathrm{~nm}$ (Chl $b$, carotenoids), $471 \mathrm{~nm}$ (carotenoids), $642 \mathrm{~nm}(\mathrm{Chl}$ b), $662 \& 680 \mathrm{~nm}(\mathrm{Chl} a$ ). Principal component analysis (PCA) was performed to identify patterns in sycamore leaf spectral data. Under in vitro conditions, as mercury concentration increased above $100 \mathrm{mg} \cdot \mathrm{kg}^{-1}$, germination of all species decreased, with P. echinata being the least sensitive. Germination was inhibited more when seeds were exposed to methyl mercury chloride than to mercuric nitrate. Organic species of mercury proved to be more toxic than inorganic species of mercury in our greenhouse study. Significant changes occurred in levels of all pigments sampled (p430, p448, p471, p642, p662, and p680) over the course of the experiment. NIR spectroscopy was not sensitive enough to detect other chemical changes to foliage following mercury application.
\end{abstract}

Keywords: Emergence; Mercuric Compounds; NIR; Pigments

\section{Introduction}

Mercury pollution is of particular importance due to its deleterious effects on aquatic plants and animals [1-3], soil microbial, plant and fungal communities [4-6]. In the 1950s (particularly 1956-1958) and early 1960s, over 1080 metric tons of mercuric nitrate and elemental mercury $(\mathrm{Hg})$ were released into the environment through the soil. Subsequently, mercury compounds were discharge into East Fork Poplar Creek (EFPC), from the US Department of Energy Y-12 site in Oak Ridge, Tennessee USA $[7,8]$. East Fork Poplar Creek's head water begins at the Y-12 Facilities located on the Oak Ridge Reservation. From the 1950s and early 1960s, mercury was used to separate lithium isotopes during the production of nuclear weapons [8]. This 15 -mile long creek flows through the city of Oak Ridge in Anderson County and empties into the Clinch River in Roane County, TN. Levels of total $\mathrm{Hg}$ in the floodplain soils along the creek ranged from 0.5 to $3000 \mathrm{mg} \cdot \mathrm{kg}^{-1}$ in 1984 [7]. Several streams of various sizes (White Oak Creek, Mitchell Branch, McCoy Branch, Bear Creek, Poplar Creek, and East Fork Poplar Creek) which run through the Oak Ridge Reservation have been heavily impacted by radionuclides, trace metals (especially mercury), and polychlorinated biphenyls. Following remediation (i.e. pump-and-treat, in-situ anaerobic bioremediation and hydrofracture) of EFPC and other tributaries by the US Department of Energy and Science Application International Corporation $[9,10]$, the total remaining soil $\mathrm{Hg}$ ranged from 0 to $200 \mathrm{mg} \cdot \mathrm{kg}^{-1}$ along transects, with some areas $>200 \mathrm{mg} \cdot \mathrm{kg}^{-1}$. Lindberg et al. [11] reported that roughly $75 \%$ of total soil $\mathrm{Hg}$ was bound to organic matter in the forest soil at Walker Branch Watershed (Tennessee). Forests of the EFPC floodplain therefore received an acute dose of mercuric nitrate and elemental Hg during the 1950s, followed by 
the chronic presence of $\mathrm{Hg}$ exposure over the past 50 years.

Several authors have investigated the seed developmental stage of the plant life cycle and the ways how essential and non-essential metal ions can affect developmental processes in vegetation [12-14]. Plant establishment can also be affected by mercury; Mishra and Choudhuri [15] observed reduction in root and shoot elongation and decreased germination in two rice cultivars exposed to $\mathrm{Pb}$ and $\mathrm{Hg}$, and noted that $\mathrm{Hg}$ was more phytotoxic than $\mathrm{Pb}$. Mercury toxicity also varies between compounds, with methylmercury being of much greater toxicity than inorganic mercury salts to a variety of life forms [16]. Within forest communities, heavy metal pollution has been shown to influence primary processes in plants, fungi, algae and bacteria [12,17,18]. However little, is known about the effects of mercury on germination or early survival of tree species. Here we evaluate the ability of, American sycamore (Platanus occidentalis), loblolly pine (Pinus echinata), and shortleaf pine (Pinus taeda) to germinate in various mercury solutions. $P$. occidentalis was selected because of its abundant presence in mercury contaminated soils along the creek bank of EFPC in Anderson and Roane Co., Tennessee. The pine species were selected due to their ability to toleratesoil exposed to heavy metals [19]. We initially determine lethal and non-lethal concentrations for each species and test whether germination rate for each species decreases as mercuric concentration increases. The results of this germination study were used to develop the appropriate $\mathrm{Hg}$ treatments solutions for the subsequent greenhouse study. We test whether an inoculation treatment using EFPC soils enhance tolerance to different mercuric applications [20], monitor early seedling survivaland measure the leaves of American sycamore using Near Infrared Spectroscopy (NIR) as a tool to monitor changes in leaves due to mercury exposure.

\section{Material and Methods}

\subsection{Germination Experimental Design}

Seeds of American sycamore, loblolly, and shortleaf pine were obtained from Sheffield Seed Company, New York. Seeds were sterilized for three minutes in a $10 \%$ bleach solution, and soaked in deionized water for 1 hour. Twenty-five seeds of pine were placed on $95 \mathrm{~mm}$ diameter Petri-plates lined with filter paper, while 50 seeds of sycamore were placed on $35 \mathrm{~mm}$ diameter Petri-plates lined with filter paper.

Stock solutions $\left(500 \mathrm{mg} \cdot \mathrm{kg}^{-1}\right)$ of mercuric nitrate $\left(\mathrm{Hg}\left(\mathrm{NO}_{3}\right)_{2}\right)$ and methyl mercury chloride $\left(\mathrm{CH}_{3} \mathrm{HgCl}\right)$ were prepared by mixing 0.27 grams of each compound in $540 \mathrm{~mL}$ of deionized water. The stock solution was further diluted to obtain final concentrations of 5, 10, 50,
100 , and $500 \mathrm{mg} \cdot \mathrm{kg}^{-1}$. Depending on plate size, either 3 or $10 \mathrm{~mL}$ of mercuric solution was applied, to saturate filter paper without submerging seeds.

Each species (sycamore, loblolly and shortleaf) was germinated in each of the two mercuric solutions (treatment), $\mathrm{Hg}\left(\mathrm{NO}_{3}\right)_{2}$ and $\mathrm{CH}_{3} \mathrm{HgCl}$. Each treatment was replicated four times. Seeds were germinated in vitro in an incubation environment based on optimum conditions [21-23]; sycamore and pine species were placed in an incubator with 8 hours of light at $30^{\circ} \mathrm{C}$ and 16 hours of dark at $20^{\circ} \mathrm{C}$. Germination percentage was recorded on day $7,9,12,22,37$, and 44 for sycamore seeds and day 7 , $13,15,22,38$, and 44 for pine species. On days $9-15$, viable seedlings from Pinus $s p$. and P. occidentalis were transplanted into sterilized 8 " pots containing $400 \mathrm{~g}$ of sterile 2:1 vermiculite/sand media.

Analysis of variance (ANOVA) was used to test for mean differences between block (experiment) by treatment interaction for each tree species for the germination study. ANOVA repeated measure combining the 4 replications using a Randomized Complete Block Design was used to test for differences in mean germination rate by tree species, mercury species, and mercury concentration, using day as a repeated measure. All data analysis was performed by SAS 9.1.3.

\subsection{Soil Sampling Experimental Design}

During June 2007, three blocks B1 (N36 00.52', W084 $\left.14^{\prime}\right)$, B2 (N36 $\left.00.33^{\prime}, \mathrm{W} 084^{\circ} 16.82^{\prime}\right)$ and B3 (N35 $95.243^{\prime}$, W084 $38.19^{\prime}$ ) were established within the floodplain of East Fork Poplar Creek (EFPC) perpendicular to the creek bank. The Natural Resources Conservation Service has classified soils along EFPC as Inceptisols. These Newark silt loams are somewhat poorly drained and are moderately acid to moderately alkaline. Historical data for soil total $\mathrm{Hg}$ concentration along EFPC obtained from Science Application International Corporation (SAIC, 1994), was used to establish plots along the creek. Three $\mathrm{Hg}$ contamination levels, low $\left(0-50 \mathrm{mg} \cdot \mathrm{kg}^{-1}\right)$, medium $\left(50-200 \mathrm{mg} \cdot \mathrm{kg}^{-1}\right)$ and high $\left(>200 \mathrm{mg} \cdot \mathrm{kg}^{-1}\right)$ were established within each of the blocks, and circular plots were randomly placed within each of these areas. Plot size was $168.1 \mathrm{~m}^{2}$ (0.017 hectare), with 3 plots each for low and medium levels, and one high level within Block 1 (1A, $1 \mathrm{~B}, 1 \mathrm{D}, 1 \mathrm{E}, 1 \mathrm{~F}, 1 \mathrm{G}, 1 \mathrm{H})$ and Block $3(3 \mathrm{~A}, 3 \mathrm{~B}, 3 \mathrm{C}, 3 \mathrm{D}$, $3 \mathrm{E}, 3 \mathrm{~F}, 3 \mathrm{G})$. Block $2(2 \mathrm{~A}, 2 \mathrm{~B}, 2 \mathrm{C})$ was smaller in area and contained one plot in each contamination level. The high/medium/low classification of some plots was later changed based on the results of our soil analysis.

\subsection{Experimental Design for Greenhouse Study}

Soil cores obtained from plots recorded as "high" plots (1D and 2A) along EFPC were used to inoculate syca- 
more seeds in plastic trays $\left(21 " \times 11^{\prime \prime} \times 2 "\right)$. Eight seed beds, (two controls, two inoculated with soil cores from plot $1 \mathrm{D}$, two inoculated with soil cores from plot $2 \mathrm{~A}$, and two inoculated with a combination of 1D and 2A (combo)) were established with all beds containing sterilized 2:1 (by volume) vermiculite/sand media. Commercial sycamore seeds of Tennessee origin were obtained from Sheffield Seed Company, New York. The seeds were sterilized for three minutes in a $10 \%$ bleach solution, soaked in deionized water for 1 hour and planted in the beds (per company protocol). The seed beds were placed in the greenhouse, allowed to establish for 2 months, and watered with $25 \%$ Hoagland's solution throughout the study [24].

After two months, the sycamore seedlings were transplanted into individual pots containing sterilized 2:1 (by volume) vermiculite/sand media (400 g per pot) and allowed to establish for an additional 6 weeks, at which point they were approximately $10 \mathrm{~cm}$ tall with several pairs of mature leaves.

We used a randomizedsplit plot design, where $\mathrm{Hg}$ treatment was the whole plot within each block. Four Hg treatments were the whole plot factors (methyl mercury chloride $\left(\mathrm{CH}_{3} \mathrm{HgCl}\right)$, mercuric nitrate $\left(\mathrm{Hg}\left(\mathrm{NO}_{3}\right)_{2}\right)$, methyl mercury chloride + mercuric nitrate $\left(\mathrm{CH}_{3} \mathrm{HgCl}+\mathrm{Hg}\left(\mathrm{NO}_{3}\right)_{2}\right)$, and no mercury). Within the whole plot, inoculant treatments were the four subplot factors $(1 \mathrm{D}, 2 \mathrm{~A}, 1 \mathrm{D}+2 \mathrm{~A}$ and no inoculate). The experimental block (B1) was replicated once. Seedlings established in the four inoculation treatments $(1 \mathrm{D}, 2 \mathrm{~A}, 1 \mathrm{D}+2 \mathrm{~A}$, and no inoculate) were randomly assigned to tubs with a total of 24 seedlings per tub (6 seedlings for each inoculate treatment). Each tub represented one of the four $\mathrm{Hg}$ treatments $\left(\mathrm{CH}_{3} \mathrm{HgCl}\right.$, $\mathrm{Hg}\left(\mathrm{NO}_{3}\right)_{2}, \mathrm{CH}_{3} \mathrm{HgCl}+\mathrm{Hg}\left(\mathrm{NO}_{3}\right)_{2}$, and no mercury). Tubs were used to keep contaminated solutions contained. Seedlings were watered once a week with either $\mathrm{Hg}\left(\mathrm{NO}_{3}\right)_{2}$, $\mathrm{CH}_{3} \mathrm{HgCl}$, a combination of $\mathrm{CH}_{3} \mathrm{HgCl}+\mathrm{Hg}\left(\mathrm{NO}_{3}\right)_{2}$ or deionized water. Mercury solution was made such that total $\mathrm{Hg}$ concentration in a liter of deionized water was $100 \mathrm{mg} \cdot \mathrm{kg}^{-1}$. Watering cans were used to directly water the leaves of the seedlings. One liter of solution was randomly applied to each of the treatments which contained 24 seedlings each. Seedlings were treated weekly from $9 / 24 / 08$ to $10 / 22 / 08$. Fifteen days (10/8/08) into the experiment seedlings, treated with any combination of methyl mercury chloride were terminated due to plant mortality. The Hg treatment continued until the completion of the experiment for seedlings that received $\mathrm{Hg}\left(\mathrm{NO}_{3}\right)_{2}$ and deionized water.

To minimize volatilization of mercuric compounds, which occurs rapidly above $30^{\circ} \mathrm{C}$, a cooling system using chilled water circulating through copper tubing was set up below the tubs to keep soil temperature at or below $30^{\circ} \mathrm{C}$ during the experiment. Soil temperature was taken three times a day (morning, afternoon and evening). The temperature during the month of September averaged $28.1^{\circ} \mathrm{C}$ during the day to $16.5^{\circ} \mathrm{C}$ at night, and during the month of October averaged $22.4^{\circ} \mathrm{C}$ during the day to $9.2^{\circ} \mathrm{C}$ at night. Daily observations were taken to note changes in foliar appearance such as color, curling and wilting.

\subsection{NIR Analysis of Sycamore Leaves}

Spectra obtained from vegetation during stress or senescencetypically show increased overall reflectance in the visible, due to loss of chlorophyll, and decreased reflectance in the NIR, due to damage to leaf cell walls and mesophyll tissue [25-27]. NIR spectra were collected from the leaves of living sycamore seedlings during the one month of mercury treatment using aportable leaf near infrared probe attached to a spectrometer (LabSpec $\AA$ Pro). Eight spectra were collected from sycamore seedlings leaves in each of the four mercury treatments on days $2,4,7,10,22$ of the experiment. We measured vegetation stress by analyzing the reflectance spectra, therefore the entire $350-2500 \mathrm{~nm}$ spectral interval was examined. After initial analysis, we focused on the following wavelengths at which the maximum peaks of chlorophyll and several carotenoids are found: $430 \mathrm{~nm}$ (Chl a), $448 \mathrm{~nm}$ (Chl $b$, carotenoids), $471 \mathrm{~nm}$ (carotenoids), $642 \mathrm{~nm}(\mathrm{Chl} b), 662 \& 680 \mathrm{~nm}(\mathrm{Chl} a)$ [28].

\subsection{Pigment Analyses}

Repeated measures ANOVA was used to test the effects of each mercury treatment $\left(\mathrm{CH}_{3} \mathrm{HgCl}, \mathrm{CH}_{3} \mathrm{HgCl}+\mathrm{Hg}\left(\mathrm{NO}_{3}\right)_{2}\right.$, $\mathrm{Hg}\left(\mathrm{NO}_{3}\right)_{2}$, control) on each of the six wavelengths characteristic of photosynthetic pigments, and collected from the visible region by near infrared spectroscopy $(430 \mathrm{~nm}$ (Chl a), $448 \mathrm{~nm}$ (Chl $b$, carotenoids), $471 \mathrm{~nm}$ (carotenoids), $642 \mathrm{~nm}(\mathrm{Chl} b), 662 \& 680 \mathrm{~nm}(\mathrm{Chl} a))$. Before analysis, $\log$ transformation of pigment data was performed to normalize the data. Since there are 6 pigments $\times 4$ treatments $\times 4$ days (96 F-test), significance levels were adjusted to minimize Type 1 error using a Bonferroni adjustment where, 4 trt $\times 4$ days $=16$ tests, so $16 / 0.05=0.003$ [29]. The new alpha, $\alpha=0.003$ was used instead of 0.05 to evaluate day test and paired days tests within each treatment. Day was a repeated measure. Statistical analyses were run in SAS 9.1.3.

\subsection{Multivariate Analyses of Spectra}

A multivariate technique is required to extract structural information from spectral data due to high inter-correlation between spectra. Principal component analysis (PCA) is an unsupervised exploratory analysis of spectral data. Outliers can be detected and patterns in spectral data, 
through grouping or clustering, are observed. Multivariate analysis of the near-infrared spectra was performed using Unscrambler v. 9.2 software (CAMO Software Inc., Woodbridge, NJ). All spectra were modified by reduction (averaging) of wavelength by 4 and mean normalized prior to PCA analyses.

\subsection{Mercury Analysis}

Sycamore seedling roots and shoots were harvested after one month of mercury treatment and analyzed for total mercury concentration. Fresh roots and shoots were rinsed in deionized water in a three step process to remove debris, and ground in liquid nitrogen. Samples were analyzed for total mercury concentration by cold vapor atomic absorption spectroscopy (CVAAS) by Western Kentucky University, Institute of Combustion Science and Environmental Technology.

\section{Result and Discussion}

\subsection{Mercuric Compounds Effect on Germination}

Both pine species germinated in $\mathrm{Hg}\left(\mathrm{NO}_{3}\right)_{2}$ and $\mathrm{CH}_{3} \mathrm{HgCl}$ solutions $\leq 500 \mathrm{ppm}$, and $\leq 100 \mathrm{ppm}$, respectively. American sycamoregerminated in $\mathrm{Hg}\left(\mathrm{NO}_{3}\right)_{2}$ and $\mathrm{CH}_{3} \mathrm{HgCl}$ solutions $\leq 10 \mathrm{ppm}$. Tukey's test for mean differences resulted in a significant interaction for loblolly pine $(\mathrm{P}<$ 0.0002 ) but, not for sycamoreand shortleaf pine for block (experiment) by treatment. The 4-way interaction was significant $(\mathrm{P}<0.001)$ so each tree species was evaluated separately for a 3-wayinteraction (mercury species $\times$ concentration $\times$ day). The data meet normality assumptions but, due to unequal variances between treatment levels a rank transformation was conducted (Table 1). Data are presented only for day 12 , when maximum total germination was recorded (Figures 1(a)-(b)).

From our germination study we can see that the ability for certain tree species to germinate in in vitro conditions depends on type of mercury compound, mercury concentration applied, and tree species. Our results show that at the highest concentration of mercuric nitrate solution both pines species germinated, but shortleaf was generally much more sensitive than loblolly to mercury treatment (Figures 1(a)-(b)). Sycamore germination was greatly affected by concentrations above $10 \mathrm{mg} \cdot \mathrm{kg}^{-1}$.

The effects of methyl mercury chloride on seed ger- mination proved to be more harmful, similar to the results of Godbold and Hutterman [4] who observed reduced root elongation in spruce seedlings exposed to $\mathrm{Pb}$ and $\mathrm{Hg}$ compounds, with methylmercury being intrinsically more toxic. After removal from mercury treatment, germinating seeds of the two pines species followed the same trend, where germinates previously exposed to methyl mercury chloride at concentrations greater than $10 \mathrm{mg} \cdot \mathrm{kg}^{-1}$ died over the following 2 week period (Figures 2(a)-(b)), and the number of sycamore surviving from any treatment was too small to analyze. However mercuric nitrate presence had no discernible negative effect on seedling survival in the post-treatment period. Fargašová [12] investigated the acute effects of five heavy metals $(\mathrm{Pb}, \mathrm{Cd}, \mathrm{Hg}, \mathrm{As}$, and $\mathrm{Cr}$ ) on seed germination and root growth of mustard seed (Sinapis alba) and found that metal addition had minimal toxic effect on mustard seed germination, but reduced root growth and nutrient uptake. Our results suggest that methylmercury chloride has a threshold level of toxicity between 10 and $50 \mathrm{mg} \cdot \mathrm{kg}^{-1}$, probably due to irreversible effects on membrane permeability, as has been previously shown for leaf tissue [30]. Acomparison of electrolyte leakage following the method of Zwiazek and Blake [31] (data not shown) showed that seedlings germinated in our $50 \mathrm{mg} \cdot \mathrm{kg}^{-1}$ treat- ment had membranepermeability that was $46 \%$ greater than that in lower methylmercury chloride and mercuric nitrate solutions, which were all similar.

\subsection{The Effect of Mercury Treatment on Sycamore Leaf Spectra}

Total $\mathrm{Hg}$ concentrations in $\mathrm{Hg}$-treated roots ranged from 638.5 to $3438 \mathrm{mg} \cdot \mathrm{kg}^{-1} \mathrm{Hg}$, whereas $\mathrm{Hg}$ in treated shoots (stem and leaf) ranged from 78.6 to $246 \mathrm{mg} \cdot \mathrm{kg}^{-1} \mathrm{Hg}$. In sycamore seedling roots from the control treatment, total Total $\mathrm{Hg}$ concentrations in $\mathrm{Hg}$-treated roots ranged from 638.5 to $3438 \mathrm{mg} \cdot \mathrm{kg}^{-1} \mathrm{Hg}$, whereas $\mathrm{Hg}$ in treated shoots (stem and leaf) ranged from 78.6 to $246 \mathrm{mg} \cdot \mathrm{kg}^{-1} \mathrm{Hg}$. In sycamore seedling roots from the control treatment, total $\mathrm{Hg}$ ranged from 3 to $17 \mathrm{mg} \cdot \mathrm{kg}^{-1} \mathrm{Hg}$. Shoots from the same samples ranged from 1.0 to $3.8 \mathrm{mg} \cdot \mathrm{kg}^{-1} \mathrm{Hg}$. These seedlings were watered with deionized water so, any $\mathrm{Hg}$ found in control seedlings roots presumably came from $\mathrm{Hg}$ vapours circulating in the air. Mercury treatments were randomly placed with dissimilar treatments adjacent to each other. Since $\mathrm{Hg}$ is very volatile, the ver-

Table 1. Effect of mercury $\times$ concentration $\times$ day on germination rate for each species.

\begin{tabular}{ccccc}
\hline Specie & Source & Num df & Den df & F-value \\
\hline Platanus occidentalis & Mer $\times$ Con $\times$ Day & 20 & 144 & 8.41 \\
Pinus echinata & Mer $\times$ Con $\times$ Day & 20 & 144 & $<.87$ \\
Pinus taeda & Mer $\times$ Con $\times$ Day & 20 & 144 & 2.19 \\
\hline
\end{tabular}




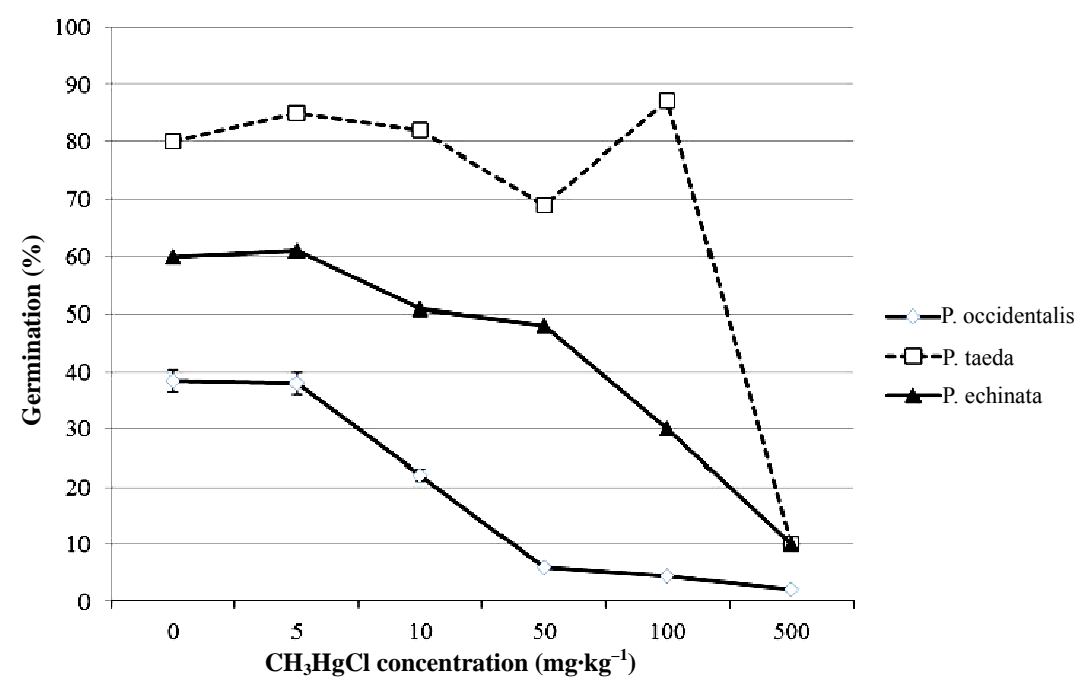

(a)

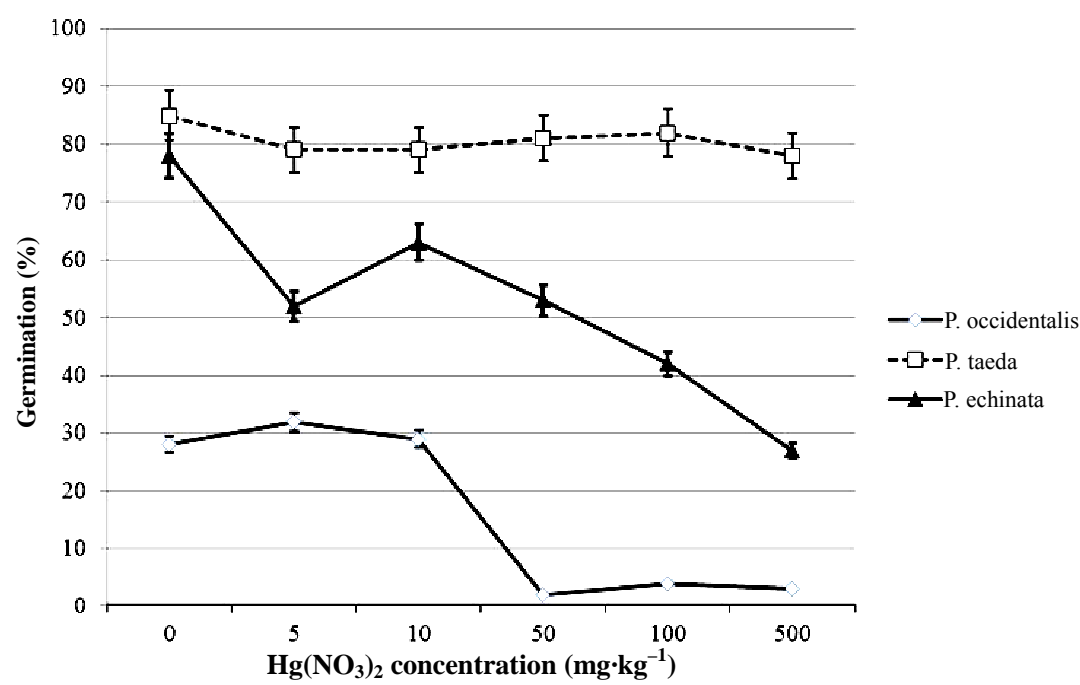

(b)

Figure 1. Mean percentage of seeds that had germinated after 12 days in (a) $\mathrm{CH}_{3} \mathrm{HgCl}$ and (b) $\mathrm{Hg}\left(\mathrm{NO}_{3}\right)_{2}$ solutions ranging from 0 to $500 \mathrm{mg} \cdot \mathrm{kg}^{-1}$. Bars indicate standard error.

miculite/sand media may have allowed volatilization of $\mathrm{Hg}$, thereby affecting all sycamore seedlings, and exposing the leaves and soil media of the control seedlings to $\mathrm{Hg}$ vapours.

Sycamore seedlings that received $\mathrm{CH}_{3} \mathrm{HgCl}$ or $\mathrm{CH}_{3} \mathrm{HgCl}$ $+\mathrm{HgNO}_{3}$ developed red discolorations on their leaves by day 6 following the initial $\mathrm{Hg}$ treatment. By day 8, early senescence and leaf wilting was apparent in all the leaves of seedlings exposed to $\mathrm{CH}_{3} \mathrm{HgCl}$. After day 11 all $\mathrm{CH}_{3} \mathrm{HgCl}$ treatments were terminated due to seedling death. Control and $\mathrm{Hg}\left(\mathrm{NO}_{3}\right)_{2}$ treatments remained viable until the completion of the experiment. Mercuric nitrate treatment had no observable effects on leaf color or health of the sycamore seedlings.

The spectra of a healthy plant has characteristic strong absorptions at $\sim 450 \mathrm{~nm}$ and $\sim 680 \mathrm{~nm}$ due to chlorophylls and strong reflectance in the NIR arising from internal scattering of light from the cell wall-air interfaces [32]. When vegetation is stressed, spectra show increased reflectance in the visible light range due to loss of chlorophyll and decreased reflectance in the NIR range.Due to damage to leaf cell walls and mesophyll tissue [25-27]. There were differences such as discoloration, wilting and curling of leaves observed especially when sycamore seedlings were watered with any methyl mercury treatment. As mentioned above, the seedlings in treatments that received methyl mercury chloride expired before the end of the experiment, so pigment analyses was conducted only on days 2, 4, 7 and 10 . We further examine the effects of each mercury treatment on each wavelength characteristic of photosynthetic pigment by days sampled (Table 2). There was an overall significant dif- 


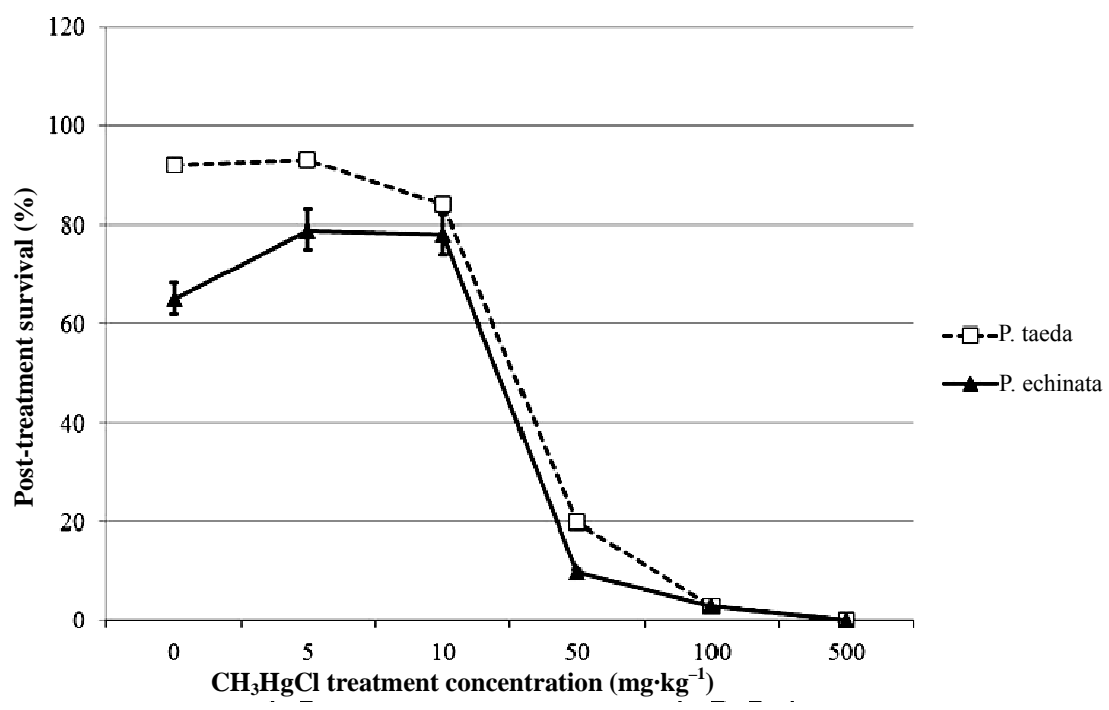

(a)

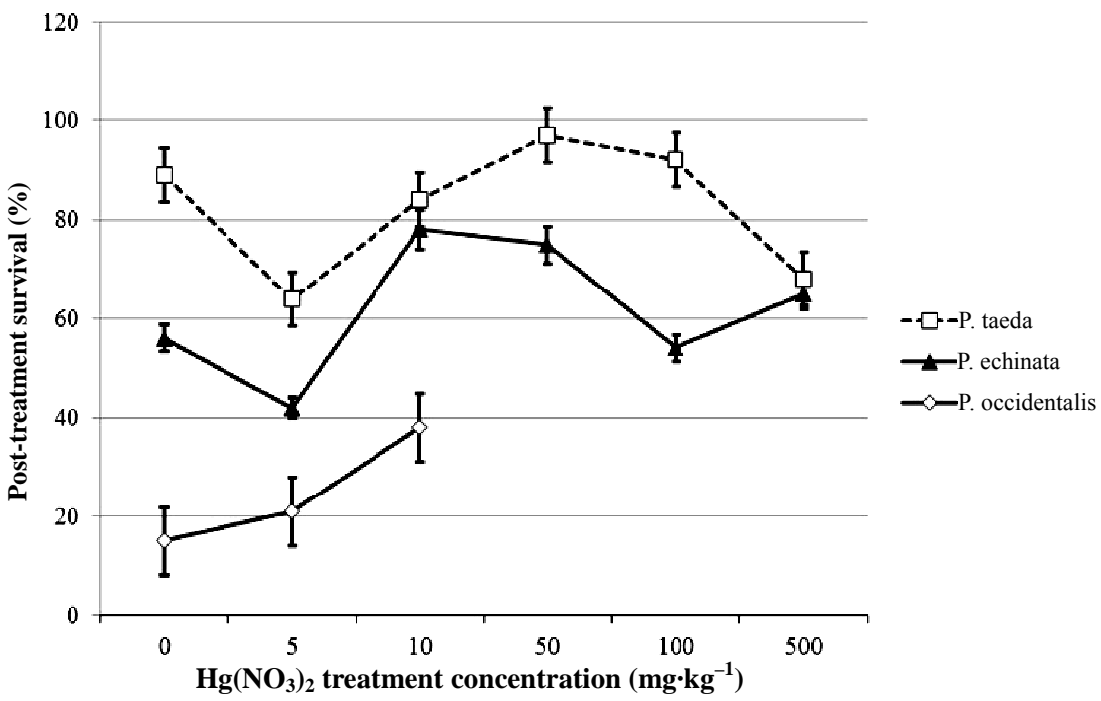

(b)

Figure 2. Mean survival after 32 days of seedlings that had been germinated in (a) $\mathrm{CH}_{3} \mathrm{HgCl}$ or $(\mathrm{b}) \mathrm{Hg}\left(\mathrm{NO}_{3}\right)_{2}$ solutions ranging from 0 to $500 \mathrm{mg} \cdot \mathrm{kg}^{-1}$, and transplanted to sterile media. Bars indicate standard error.

ference $(\mathrm{P}<0.001)$ in all pigment wavelengths sampled (p430, p448, p471, p642, p662, and p680), when we analyzed each treatment by day. Seedlings on day 2, 4, 7 had leaves with pigments (p430, p448, p471, and p680) that were significantly different between $\mathrm{Hg}\left(\mathrm{NO}_{2}\right)_{3}$ and $\mathrm{CH}_{3} \mathrm{HgCl}$ treatments, and combo and control treatments were significantly different on day 2 . Interestingly for chl $a$ and chl $b$ (p642 and p662), seedlings on day 2 were significantly different $(\mathrm{P}<0.0001)$ from day 4 , but not from days 7 or 10 for $\mathrm{Hg}\left(\mathrm{NO}_{2}\right)_{3}$ and $\mathrm{CH}_{3} \mathrm{HgCl}$ treatments. When plants are under stress or during senescence, chlorophyll tends to decline more rapidly than carotenoids [33]. Pigments are important for leaf function, and variations in pigment content may provide information concerning the physiological state of leaves.

\subsection{NIR Analysis of Sycamore Leaves}

To further examine the effects of mercury on leaf chemistry we explored spectra in the near infrared region, 1.0 to $2.5 \mu \mathrm{m}(1000-2500 \mathrm{~nm})$ of the mercury treated sycamore leaves by day and mercury treatment. Near-infrared spectra were visually similar, showing two bands at 1443 $\mathrm{nm}$ and $1930 \mathrm{~nm}$ over the selected spectral range (Figure 3). Several possible compounds in plant leaf tissue, such as water (with peaks at 1430 and $1930 \mathrm{~nm}$ ), starch (with peaks at 990, 1220, 1450, 1560, 1700, 1770, $1930 \mathrm{~nm}$ ) or cellulose $(1200,1480,1930 \mathrm{~nm})$ could be possible absorptive components present. Water has been shown to mask the absorption features of plant compounds (i.e. cellulose, starch, lignin, etc.) in the NIR [34]. 
Table 2. Mean reflectance at six wavelengths (p430, p448, p471, p642, p662, p680) for sycamore seedling leaves on days $2,4,7$, and 10 during mercury treatment.

\begin{tabular}{|c|c|c|c|c|}
\hline Day & 2 & 4 & 7 & 10 \\
\hline \multicolumn{5}{|l|}{ p430 } \\
\hline $\mathrm{Hg}\left(\mathrm{NO}_{3}\right)_{2}$ & $0.05^{\mathrm{C}} \pm 0.01$ & $0.15^{\mathrm{A}} \pm 0.02$ & $0.10^{\mathrm{B}} \pm 0.06$ & $0.12^{\mathrm{AB}} \pm 0.08$ \\
\hline $\mathrm{CH}_{3} \mathrm{HgCl}$ & $0.05^{\mathrm{C}} \pm 0.01$ & $0.14^{\mathrm{A}} \pm 0.01$ & $0.12^{\mathrm{B}} \pm 0.13$ & $0.12^{\mathrm{AB}} \pm 0.05$ \\
\hline Combo & $0.04^{\mathrm{B}} \pm 0.01$ & $0.14^{\mathrm{A}} \pm 0.01$ & $0.18^{\mathrm{A}} \pm 0.23$ & $0.11^{\mathrm{A}} \pm 0.01$ \\
\hline Control & $0.05^{\mathrm{B}} \pm 0.02$ & $0.16^{\mathrm{A}} \pm 0.03$ & $0.13^{\mathrm{A}} \pm 0.02$ & $0.16^{\mathrm{A}} \pm 0.13$ \\
\hline \multicolumn{5}{|l|}{ p448 } \\
\hline $\mathrm{Hg}\left(\mathrm{NO}_{3}\right)_{2}$ & $0.05^{\mathrm{C}} \pm 0.02$ & $0.15^{\mathrm{A}} \pm 0.02$ & $0.10^{\mathrm{B}} \pm 0.06$ & $0.13^{\mathrm{AB}} \pm 0.08$ \\
\hline $\mathrm{CH}_{3} \mathrm{HgCl}$ & $0.05^{\mathrm{C}} \pm 0.01$ & $0.14^{\mathrm{A}} \pm 0.01$ & $0.12^{\mathrm{B}} \pm 0.14$ & $0.13^{\mathrm{AB}} \pm 0.06$ \\
\hline Combo & $0.04^{\mathrm{B}} \pm 0.01$ & $0.15^{\mathrm{A}} \pm 0.01$ & $0.18^{\mathrm{A}} \pm 0.23$ & $0.12^{\mathrm{A}} \pm 0.01$ \\
\hline Control & $0.05^{\mathrm{B}} \pm 0.02$ & $0.16^{\mathrm{A}} \pm 0.03$ & $0.14^{\mathrm{A}} \pm 0.02$ & $0.17^{\mathrm{A}} \pm 0.14$ \\
\hline \multicolumn{5}{|l|}{ p471 } \\
\hline $\mathrm{Hg}\left(\mathrm{NO}_{3}\right)_{2}$ & $0.05^{\mathrm{C}} \pm 0.02$ & $0.17^{\mathrm{A}} \pm 0.02$ & $0.11^{\mathrm{B}} \pm 0.07$ & $0.14^{\mathrm{AB}} \pm 0.09$ \\
\hline $\mathrm{CH}_{3} \mathrm{HgCl}$ & $0.05^{\mathrm{C}} \pm 0.01$ & $0.16^{\mathrm{A}} \pm 0.01$ & $0.14^{\mathrm{B}} \pm 0.16$ & $0.14^{\mathrm{AB}} \pm 0.07$ \\
\hline Combo & $0.04^{\mathrm{B}} \pm 0.01$ & $0.16^{\mathrm{A}} \pm 0.01$ & $0.20^{\mathrm{A}} \pm 0.23$ & $0.13^{\mathrm{A}} \pm 0.01$ \\
\hline Control & $0.06^{\mathrm{B}} \pm 0.02$ & $0.18^{\mathrm{A}} \pm 0.04$ & $0.16^{\mathrm{A}} \pm 0.03$ & $0.19^{\mathrm{A}} \pm 0.16$ \\
\hline \multicolumn{5}{|l|}{ p642 } \\
\hline $\mathrm{Hg}\left(\mathrm{NO}_{3}\right)_{2}$ & $0.11^{\mathrm{CB}} \pm 0.03$ & $0.36^{\mathrm{A}} \pm 0.06$ & $0.22^{\mathrm{B}} \pm 0.13$ & $0.25^{\mathrm{B}} \pm 0.14$ \\
\hline $\mathrm{CH}_{3} \mathrm{HgCl}$ & $0.11^{\mathrm{C}} \pm 0.02$ & $0.36^{\mathrm{A}} \pm 0.08$ & $0.29^{\mathrm{B}} \pm 0.25$ & $0.36^{\mathrm{AB}} \pm 0.16$ \\
\hline Combo & $0.10^{\mathrm{B}} \pm 0.02$ & $0.41^{\mathrm{A}} \pm 0.07$ & $0.43^{\mathrm{A}} \pm 0.20$ & $0.38^{\mathrm{A}} \pm 0.10$ \\
\hline Control & $0.13^{\mathrm{B}} \pm 0.03$ & $0.40^{\mathrm{A}} \pm 0.11$ & $0.38^{\mathrm{A}} \pm 0.05$ & $0.37^{\mathrm{A}} \pm 0.21$ \\
\hline \multicolumn{5}{|l|}{ p662 } \\
\hline $\mathrm{Hg}\left(\mathrm{NO}_{3}\right)_{2}$ & $0.07^{\mathrm{CB}} \pm 0.02$ & $0.23^{\mathrm{A}} \pm 0.03$ & $0.16^{\mathrm{B}} \pm 0.10$ & $0.19^{\mathrm{AB}} \pm 0.12$ \\
\hline $\mathrm{CH}_{3} \mathrm{HgCl}$ & $0.07^{\mathrm{C}} \pm 0.02$ & $0.23^{\mathrm{A}} \pm 0.03$ & $0.21^{\mathrm{B}} \pm 0.22$ & $0.24^{\mathrm{AB}} \pm 0.13$ \\
\hline Combo & $0.06^{\mathrm{B}} \pm 0.01$ & $0.25^{\mathrm{A}} \pm 0.03$ & $0.30^{\mathrm{A}} \pm 0.22$ & $0.24^{\mathrm{A}} \pm 0.05$ \\
\hline Control & $0.08^{\mathrm{B}} \pm 0.02$ & $0.26^{\mathrm{A}} \pm 0.07$ & $0.25^{\mathrm{A}} \pm 0.04$ & $0.27^{\mathrm{A}} \pm 0.19$ \\
\hline \multicolumn{5}{|l|}{ p680 } \\
\hline $\mathrm{Hg}\left(\mathrm{NO}_{3}\right)_{2}$ & $0.07^{\mathrm{C}} \pm 0.02$ & $0.24^{\mathrm{A}} \pm 0.02$ & $0.16^{\mathrm{B}} \pm 0.10$ & $0.19^{\mathrm{AB}} \pm 0.11$ \\
\hline $\mathrm{CH}_{3} \mathrm{HgCl}$ & $0.06^{\mathrm{C}} \pm 0.01$ & $0.24^{\mathrm{A}} \pm 0.02$ & $0.19^{\mathrm{B}} \pm 0.21$ & $0.21^{\mathrm{AB}} \pm 0.11$ \\
\hline Combo & $0.06^{\mathrm{B}} \pm 0.01$ & $0.24^{\mathrm{A}} \pm 0.02$ & $0.27^{\mathrm{A}} \pm 0.23$ & $0.21^{\mathrm{A}} \pm 0.02$ \\
\hline Control & $0.07^{\mathrm{B}} \pm 0.02$ & $0.25^{\mathrm{A}} \pm 0.05$ & $0.25^{\mathrm{A}} \pm 0.04$ & $0.27^{\mathrm{A}} \pm 0.19$ \\
\hline
\end{tabular}

Means and their corresponding letters are listed. Means with the same letter labels are not significantly different.

Principal component analysis (PCA) was performed only on days 2,4 , and 10 due to a shift in the spectral data on day seven. Analysis was conducted on the whole

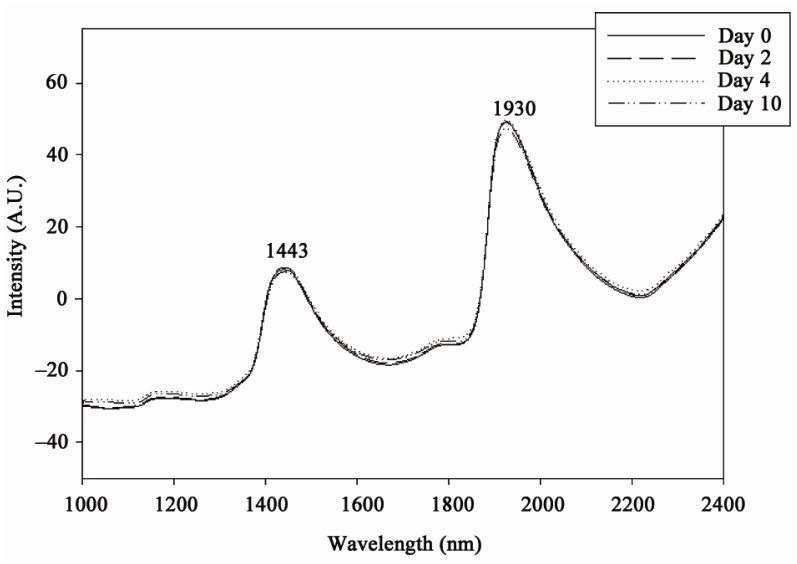

Figure 3. Near-infrared spectra averaged across sampling days, from leaves of sycamore seedlings from baseline (day 0, 2), $\mathrm{Hg}\left(\mathrm{NO}_{3}\right)_{2}, \mathrm{CH}_{3} \mathrm{HgCl}$, and $\mathrm{Hg}\left(\mathrm{NO}_{3}\right)_{2}+\mathrm{CH}_{3} \mathrm{HgCl}$ (day 4, 10).

data setto determine variations between mercury-treated and control seedlings (Figure 4). Following mercury treatment on day 2 , there were no differences in mercurytreated and control leaves indicating that mercury treatments had not affected seedling tissue, but on day 4, there seemed to be a chemical change in all leaves when analyzed by NIR. Even though control seedlings received deionized water, mercury was found in the roots $(<16$ $\left.\mathrm{mg} \cdot \mathrm{kg}^{-1}\right)$ and shoots (leaves and stems) $\left(<3 \mathrm{mg} \cdot \mathrm{kg}^{-1}\right)$ of these seedlings when analyzed post experiment. Control treatments were randomly placed alongside mercury treatments to ensure the same experimental regime. All treatments were administered as a solution where sycamore seedlings were randomly watered.

Mercury is very volatile in air, so when room temperature is greater than $30^{\circ} \mathrm{C}$, the concentration of mercury vapour in the air is greatly increased. The levels of mercury in control seedlings were minute as compared to mercury treated seedlings, where roots had concentrations of $>700 \mathrm{mg} \cdot \mathrm{kg}^{-1}$ and shoots had concentrations $>75$ $\mathrm{mg} \cdot \mathrm{kg}^{-1}$ mercury. Even though the mercury levels in the control seedlings were significantly lower than in mercury-treated seedlings, NIR spectroscopy was not sensitive enough to detect chemical changes following mercury application. Finally, when sycamore leaves were analyzed by the NIR probe, several leaves were burned, which may have caused chemical changes in the plant leaf tissue.

\section{Acknowledgements}

Financial support for this research was provided by The Southern Regional Education Board (SREB) and the Department of Forestry Wildlife and Fisheries. Thank you to the Department of Energy for access to sampling sites. 


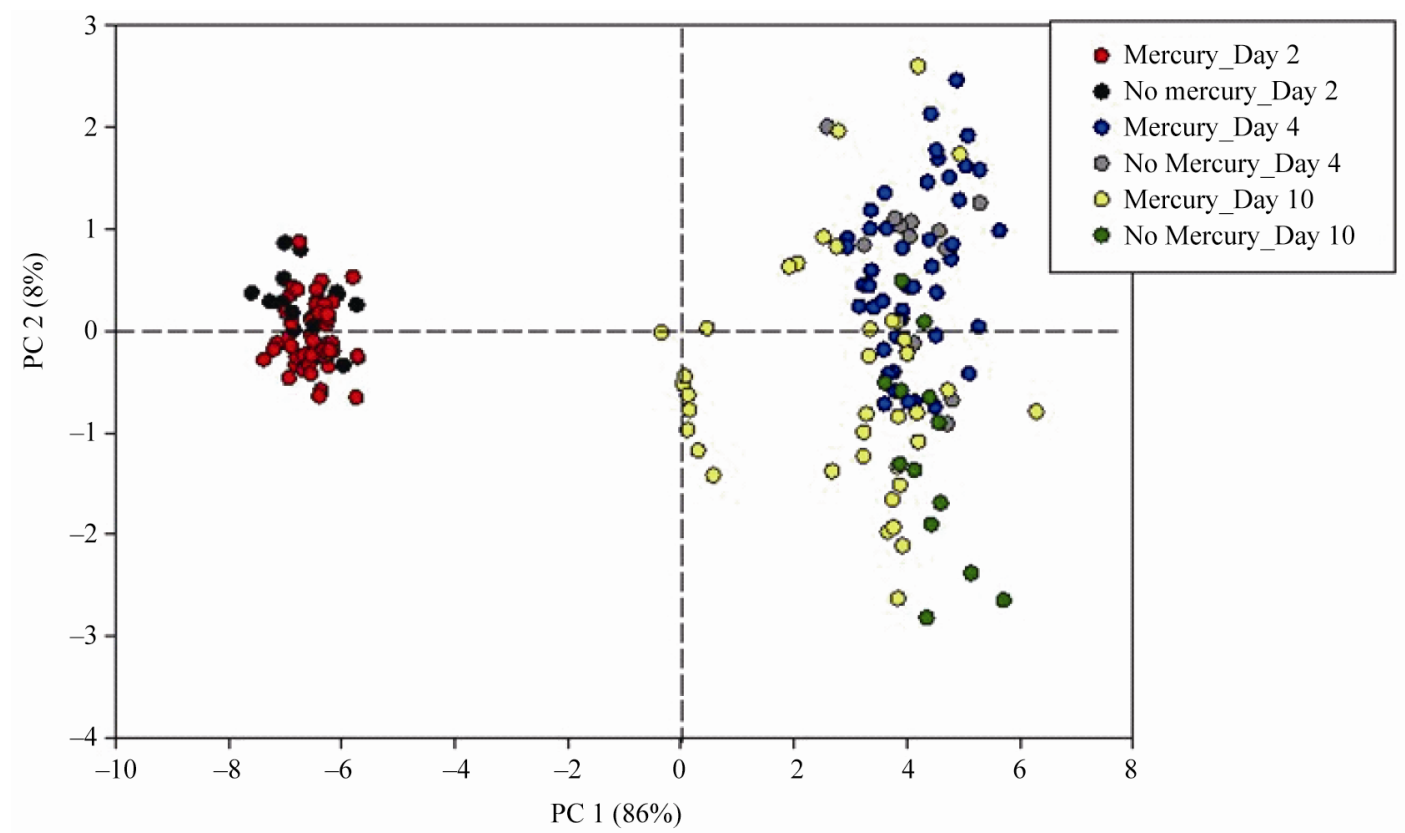

Figure 4. Principal component analysis (PCA) score plot of spectra from leaves treated with deionized water, $\left.\mathrm{Hg}_{(\mathrm{NO}}\right)_{2}$, $\mathrm{CH}_{3} \mathrm{HgCl}$ and $\mathrm{Hg}\left(\mathrm{NO}_{3}\right)_{2}+\mathrm{CH}_{3} \mathrm{HgCl}$.

\section{REFERENCES}

[1] J. Burger, K. Campbell, T. Campbell, T. Shukla, C. Dixon and M. Gochfeld, "Use of Central Stonerollers (Cyprinidae: Campostoma Anomalum) from Tennessee as a Bioindicator of Metal Contamination," Environmental Monitoring and Assessment, Vol. 110, No. 1-3, 2005, pp. 171-184. doi:10.1007/s10661-005-6689-8

[2] K. Campbell, T. Campbell and J. Burger, "Heavy Metal Concentration in Northern Water Snakes (Nerodia Sipedon) from East Fork Poplar Creek and the Little River, East Tennessee, USA," Archives of Environmental Contamination and Toxicology, Vol. 49, No. 2, 2005, pp. 239-248. doi:10.1007/s00244-004-0200-3

[3] C. Theodorakis, C. Swartz, W. Rogers, J. Bickham, K. Donnelly and S. Adams, "Relationship between Genotoxicity, Mutagenicity, and Fish Community Structure in a Contaminated Stream," Journal of Aquatic Ecosystem Stress and Recovery, Vol. 7, No. 2, 2000, pp. 131-143. doi:10.1023/A:1009971330138

[4] D. L. Godbold and A. Huttermann, "The Uptake and Toxicity of Mercury and Lead to Spruce (Picea Abies Karst.) Seedlings," Water Air and Soil Pollution, Vol. 31, No. 1-2, 1986, pp. 509-515. doi:10.1007/BF00630869

[5] H. Munthe and A. Iverfeldt, "Mechanisms of Deposition and Mercury and Methylmercury to Coniferous Forests," Water Air and Soil Pollution, Vol. 80, No. 1-4, 1995, pp. 363-371. doi:10.1007/BF01189686

[6] Y. Tsai and B. Olson, "Effects of $\mathrm{Hg}^{2+}, \mathrm{CH}_{3}-\mathrm{Hg}^{+}$, and Temperature on the Expression of Mercury Resistance Genes in Environmental Bacteria," Applied Environmental Microbiology, Vol. 56, 1990, pp. 3266-3272.

[7] N. W. Revis, T. R. Osborne, G. Holdsworth and C. Hadden, "Distribution of Mercury Species in Soil from a
Mercury-Contaminated Site," Water Air and Soil Pollution, Vol. 45, 1989, pp. 105-113.

[8] F. X. Han, Y. M. Su, L. David, C. A. Waggoner and M. J. Plodinec, "Binding, Distribution, and Plant Uptake of Mercury in a Soil from Oak Ridge, Tennessee, USA," Science of the Total Environment, Vol. 368, No. 2-3, 2006, pp. 753-768. doi:10.1016/j.scitotenv.2006.02.026

[9] USEPA, "National Priorities Listed for Uncontrolled Hazardous Waste Sites," Federal Register, Vol. 54, No. 223, 1989, pp. 48184-48189.

[10] Science Application International Corporation, "East Fork Poplar Creek-Sewer Line Beltway Remedial Investigation Report: Addendum," Oak Ridge, US Department of Energy, 1994.

[11] S. E. Lindberg, R. R. Turner, T. P. Meyers, G. E. Taylor and W. H. Schroder, "Atmospheric Concentrations and Deposition of $\mathrm{Hg}$ to a Deciduous Forest Walker Branch Watershed, Tennessee, USA," Water Air and Soil Pollution, Vol. 56, No. 1, 1991, pp. 577-594. doi:10.1007/BF00342301

[12] A. Fargasova, "Effect of $\mathrm{Pb}, \mathrm{Cd}, \mathrm{Hg}$, As and $\mathrm{Cr}$ on Germination and Root Growth of Sinapis alba Seeds," Bulletin of Environmental Contamination Toxicology, Vol. 52, No. 3, 1994, pp. 452-456. doi:10.1007/BF00197836

[13] W. Li, M. A. Khan, S. Yamaguchi and Y. Kamiva, "Effects of Heavy Metals on Seed Germination and Early Seedling Growth of Arabidopsis Thaliana," Plant Growth Regulation, Vol. 46, No. 1, 2005, pp. 45-50. doi:10.1007/s10725-005-6324-2

[14] O. Munzuroglu and H. Geckil, "Effects of Metals on Seed Germination, Root Elongation, and Coleoptiles and Hypocotyls Growth in Triticum Aestivum and Cucumis Sativus," Archives of Environmental Contamination and 
Toxicology, Vol. 43, No. 2, 2002, pp. 203-213. doi:10.1007/s00244-002-1116-4

[15] A. Mishra and M. A. Choudhuri, "Monitoring of Phytotoxicity of Lead and Mercury from Germination and Early Seedling Growth Indices in Tow Rice Cultivars," Water Air and Soil Pollution, Vol. 114, No. 3-4, 1998, pp. 339-346. doi:10.1023/A:1005135629433

[16] M. Patra and A. Sharma, "Mercury Toxicity in Plants," Botany Review, Vol. 66, No. 3, 2000, pp. 379-422. doi:10.1007/BF02868923

[17] W. Beauford, J. Barber and A. R. Barrington, "Uptake and Distribution of Mercury within Higher Plants," Physiology Plantarum, Vol. 39, No. 4, 1977, pp. 261-265. doi:10.1111/j.1399-3054.1977.tb01880.x

[18] D. L. Godbold, "Mercury-Induced Root Damage in Spruce Seedling," Water Air and Soil Pollution, Vol. 56, No. 1, 1991, pp. 823-831. doi:10.1007/BF00342319

[19] H. S. Helmisaari, J. Derome, H. Fritze, T. Nieminen, K. Palmgren, M. Salemaa and I. Vanha-Majamaa, "Copper in Scots Pine Forest around a Heavy-Metal Smelter in South-Western Finland," Water Air and Soil Pollution, Vol. 85, No. 3, 1995, pp. 1727-1732. doi:10.1007/BF00477229

[20] S. R. Jean-Philippe, J. A. Franklin, D. Buckley and K. Hughes, "The Effect of Mercury on Tree and Their Mycorrhizal Fungi," Environmental Pollution, Vol. 159, No. 10, 2011, pp. 2733-2739. doi:10.1016/j.envpol.2011.05.017

[21] F. T. Bonner, "Storage of Seeds," In: F. T. Bonner and R. P. Karrfalt, Eds., The Woody Plant Seed Manual, Agriculture Hand Book 727, USDA Forest Service, 2008, pp. 85-87.

[22] S. L. Krugman and J. L. Jenkinson, "Pinus L. (Pine)," In: F. T. Bonner and R. P. Karrfalt, Eds., The Woody Plant Seed Manual, Agriculture Hand Book 727, USDA Forest Service, 2008, pp. 809-847.

[23] J. C. Zasada and T. F. Strong, “Acer L. Maple,” Woody Plant Seed Manual, 2003.

[24] D. R. Hoagland and D. I. Arnon, "The Water Culture Method for Growing Plants without Soil," California Agriculture Experimental Station, 1938, p. 347.

[25] M. J. Boyer, M. Miller, M. Belanger and E. Hare. "Se- nescence and Spectral Reflectance in Leaves of Northern Pin Oak (Quercu palustris Muenchh)," Remote Sensing of Environment, Vol. 25, No. 1, 1988, pp. 71-87. doi:10.1016/0034-4257(88)90042-9

[26] G. A. Carter, "Ratios of Leaf Reflectances in Narrow Wavebands as Indicators of Plant Stress," International Journal of Remote Sensing, Vol. 15, No. 3, 1994, pp. 697703. doi:10.1080/01431169408954109

[27] K. L. Smith, M. D. Steven and J. J. Colls, "Spectral Responses of Pot-Grown Plants to Displacement of Soil Oxygen," International Journal of Remote Sensing, Vol. 25, 2004, pp. 4395-4410.

[28] S. C. Dunagan, M. S. Gilmore and J. C. Varekamp, "Effects of Mercury on Visible/Near-Infrared Reflectance Spectra of Mustard Spinach Plants (Brassica rapa P.)," Environmental Pollution, Vol. 148, 2007, pp. 301-311.

[29] J. M. Bland and D. G. Altman, "Calculating Correlation Coefficients with Repeated Observations: Part 1-Correlation within Subjects," British Medical Journal, Vol. 310, 1995, p. 446. doi:10.1136/bmj.310.6977.446

[30] M. C. Cang, "Harmful Effects of $\mathrm{Hg}$ on Cell Membranes of Rape Leaves and the Cell's Endogenous Protection," Chinese Journal of Applied Ecology, Vol. 9, No. 3, 1998, pp. 323-326.

[31] J. J. Zwiazek and T. J. Blake, "Early Detection of Membrane Injury in Black Spruce (Picea Mariana)," Canadian Journal of Forest Research, Vol. 21, No. 3, 1991, pp. 401-404. doi:10.1139/x91-050

[32] J. T. Wooley, "Reflectance and Transmittance of Light by Leaves," Plant Physiology, Vol. 47, No. 5, 1971, pp. 656662. doi: $10.1104 / p p .47 .5 .656$

[33] D. Sims and J. Garmon, "Relationship between Leaf Pigment Content and Spectral Reflectance across a Wide Range of Species, Leaf Structures and Developmental Stages," Remote Sensing of Environment, Vol. 81, No. 2-3, 2002, pp. 337-354. doi:10.1016/S0034-4257(02)00010-X

[34] C. D. Elvidge, "Visible and Near-Infrared Reflectance Characteristics of Dry Plant Materials," International Journal of Remote Sensing, Vol. 11, No. 10, 1990, pp. 1775-1795. doi:10.1080/01431169008955129 